\title{
Rapid catalyst evaluation for Sonogashira coupling in continuous flow
}

\author{
Bernadett Borcsek, György Bene, Gábor Szirbik, György Dormán,* Richard Jones, \\ László Ürge, and Ferenc Darvas
}

ThalesNano Inc., Záhony u. 7. H-1031 Budapest, Hungary

E-mail: gyorgy.dorman@thalesnano.com

Dedicated to Professor Ferenc Fülöp on the occasion of his $60^{\text {th }}$ birthday

\begin{abstract}
Selection of the most appropriate catalyst for Pd-catalyzed Sonogashira coupling often requires time and resources. We applied a continuous flow device for rapid catalyst screening of 4 heterogeneous catalysts over 6 Sonogashira coupling reactions together with longevity estimation. The screening procedure requires only 8 hours. For coupling the alkynes with 4iodo-anisole Fibrecat types of catalysts showed the highest performance, while when 4-bromoanisole was applied as an aromatic halide $\mathrm{PdCl}_{2}\left(\mathrm{PPh}_{3}\right)_{2}$ DVB gave superior results. For phenylacetylene and ethynyl-cyclohexene the coupling of the bromo derivative resulted in relatively low conversion as well as selectivity for most of the polymer-bound catalysts. Applying the cheap catalyst $10 \% \mathrm{Pd} / \mathrm{C}$ the coupling reaction could only be achieved with the rather reactive 4iodo-anisole although with moderate conversion.
\end{abstract}

Keywords: Sonogashira coupling, continuous flow, microreactor, immobilized catalysts, catalyst screening

\section{Introduction}

Pd-catalyzed Sonogashira coupling is currently the most practical method for synthesizing aryl(vinyl) acetylenes from the corresponding terminal alkynes and aryl halides. The reaction was first reported by Kenkichi Sonogashira and Nobue Hagihara in $1975 .{ }^{1}$ Since then numerous variations of the reaction were reported ${ }^{2}$ under traditional batch conditions including copper-free applications that reduced the dimerization (self-coupling) of the acetylenic species (Glaser coupling). Over 100 different conditions were applied for the synthesis of 1-methoxy-4-(2phenylethynyl)benzene from 4-iodo-anisole and phenyl-acethylene. The different users varied the catalyst (heterogeneous or homogeneous Pd species with or without copper and/or phosphine ligands) as well as other (post)transition metal catalysts such as $\mathrm{Fe}, \mathrm{Sm}, \mathrm{In}$ ), inorganic or organic 
bases, various protic solvents including water were applied. The reaction can be carried out from r.t. to $175{ }^{\circ} \mathrm{C}$, although heating reduces the reaction time significantly. MW irradiation is particularly efficient, Awuah reported a homogeneous phase Pd catalyzed copper-free procedure under less than an hour $\left(\mathrm{t}=0.5 \mathrm{~h}, \mathrm{~T}=90^{\circ} \mathrm{C}\right){ }^{3}$ Pure microwave-assisted Sonogashira reaction was also attempted without any catalysts but the yield was significantly lower than the catalytic process (tetrabutylammomium bromide, sodium carbonate in water, Time $=0.25 \mathrm{~h}, \mathrm{~T}=175^{\circ} \mathrm{C}$ ).$^{4,5}$ Interestingly $\mathrm{Pd}$-free copper catalyzed reaction was also reported with excellent yield using tetrabutylammomium bromide, potassium carbonate, triphenylphosphine and copper(l) iodide in water: reaction time $=0.7 \mathrm{~h}, \mathrm{~T}=120{ }^{\circ} \mathrm{C}$ under microwave irradiation. ${ }^{6}$

Continuous flow (micro)reactors offer several advantages. They extend the parameter space of chemical reactions significantly (up to $350{ }^{\circ} \mathrm{C}$ and 200 bar); increase reaction rates via enhanced heat/mass transfer (flash heating); enhance reproducibility and speed up optimization of reaction parameters due to fast and accurate changing of temperature and pressure parameters; prevent by-product formation by moving the reagents away from the reaction zone right after they form the desired product; allow the control of the selectivity through fine tuning the residence time. Flow reactors offer a viable alternative solution to microwave-assisted batch chemistry. ${ }^{7}$ Various microfluidic/flow or microreactor approaches were reported in the recent years for Sonogashira coupling. For example the reaction was performed in an ionic liquid ([BMIm] $\left.\left[\mathrm{PF}_{6}\right]\right)$ in the absence of a copper salt using $\mathrm{PdCl}_{2}\left(\mathrm{PPh}_{3}\right)_{2}{ }^{8}$ Kawanami applied high $\mathrm{T} / \mathrm{p}$ water containing sodium hydroxide and palladium dichloride in a homogeneous microfluidic system (with fluid channels typically in the submillimeter range) applying residence time $=0.1-$ $4.0 \mathrm{~s}, \mathrm{~T}=250{ }^{\circ} \mathrm{C}, \mathrm{p}=160 \mathrm{bar}^{9}$ In another homogenous flow approach Sugimoto applied a loop reactor (1000 $\mu \mathrm{m}$ i.d., $10 \mathrm{~m}$ length) mixing the alkyl halide and the alkyne in DMF and using $\mathrm{PdCl}_{2}\left(\mathrm{PPh}_{3}\right)_{2}(1 \mathrm{~mol} \%), \mathrm{CuBr}(2 \mathrm{~mol} \%)$, and diisopropylethylamine as a base at $120{ }^{\circ} \mathrm{C} .{ }^{10}$

The application of heterogeneous catalysis in conjunction with microreactor technology can facilitate a cleaner/green and scalable flow methodology for coupling reactions. As the most simple solution microtubular („loop”) reactors were coated with thin catalytic metal inner surface ( $\mathrm{Pd}$ or $\mathrm{Pd}-\mathrm{Cu}$ alloy) and applied in high pressure and high-temperature water $\left(\mathrm{HPHT}-\mathrm{H}_{2} \mathrm{O}\right)$ in flow. Under the optimized reaction conditions of $250{ }^{\circ} \mathrm{C}$ and 160 bar of pressure the coupling reaction was carried out in good yield and $100 \%$ selectivity within a very short residence time of $\sim 1.6$ s. $^{11}$

More frequently immobilized/heterogenized catalysts ${ }^{12}$ have been utilized to promote a range of cross-coupling reactions including Heck, Sonogashira, Suzuki, etc.. ${ }^{13,14}$ Transition metal catalysts such as palladium, copper, ruthenium, and nickel are described on silica, monolithic, magnetic nanoparticles and polymer supports. ${ }^{15}$ Flow-through microreactors using poly(chloromethylstyrene-co-divinylbenzene) monolith in capillaries of internal diameter 250 um were used successfully for Suzuki-Miyaura and Sonogashira reactions, with very low palladium leaching. ${ }^{16}$

We applied immobilized catalysts in a fixed-bed flow reactor developed for heterogeneous flow hydrogenation, H-Cube. ${ }^{17}$ The H-Cube system is also suitable for any heterogeneous 
catalytic reactions including cross coupling using immobilized transition metal catalysts in prepacked-columns , catalyst cartridges" (CatCart). The CatCart system was designed to make the use of pyrophoric catalysts safer and easier to handle, and reusable with different substrates. ${ }^{18}$ The CatCart system has number of advantages: it has a filter at each end which means the catalyst stays in the CatCart, therefore, no filtering is needed and the catalyst can be reused. Furthermore, the catalyst handling is easy because no weighing out or disposal are required.

For $\mathrm{mg}$ to $\mathrm{g}$ scale operation $70 \mathrm{~mm}$ standard catalyst cartridges are applied and we have chosen this size in the current study. The void volume for $70 \mathrm{~mm}$ cartridges is between $0.5-0.8 \mathrm{~mL}$ (for $10 \% \mathrm{Pd} / \mathrm{C}: 0.669 \mathrm{~mL}$ ), thus, the estimated residence time at $0.1 \mathrm{~mL} / \mathrm{min}$ flow rates are between 5-8 min. Such short residence time means that reactions are less likely to react again with themselves and form side products. In the CatCart system the catalyst should have a greater longevity since any product which may poison the catalyst is removed continuously from the catalyst. In a batch reactor, the product remains with the catalyst and can lead to deactivation.

The objective of our study was to determine which commercial immobilized catalysts perform best in the CatCart system for Sonogashira reaction. We tested 3 polymer-bound catalysts and in addition $10 \% \mathrm{Pd} / \mathrm{C}$ (Table 1.)

Table 1. List and properties of commercial immobilized catalysts involved in the study

\begin{tabular}{|c|c|c|c|c|c|}
\hline Catalyst & Source & Composition & $\begin{array}{l}\text { Weight in } \\
70 \mathrm{~mm} \\
\text { column } \\
(\mathrm{g})\end{array}$ & $\begin{array}{c}\text { Pd } \\
\text { content } \\
{[\mathrm{mmol} / \mathrm{g}]}\end{array}$ & $\begin{array}{l}\text { Load: } \\
\text { mmol } \\
\text { /catca } \\
\text { rt }\end{array}$ \\
\hline \multirow{3}{*}{$\begin{array}{l}\mathrm{PdCl}_{2}\left(\mathrm{PPh}_{3}\right)_{2} \\
\mathrm{DVB}\end{array}$} & & Dichlorobis(triphenylphosphin & & & \\
\hline & Sigma & e)palladium(II) $2 \%$ cross- & & & \\
\hline & Aldrich $^{19}$ & linked with divinylbenzene & 0.6 & 0.9 & 0.54 \\
\hline Fibrecat 1001, & $\begin{array}{l}\text { Johnson } \\
\text { Matthey }^{20}\end{array}$ & $\begin{array}{l}\text { Palladium(II) Acetate- } \\
\text { Triphenylphosphine } \\
\text { polyethylene fibres }\end{array}$ & 0.242 & 0.47 & 0.114 \\
\hline & Johnson & $\begin{array}{c}\text { Palladium(II) Acetate- } \\
\text { Dicyclohexyl-phenylphosphine }\end{array}$ & & & \\
\hline Fibrecat 1007, & Matthey & polyethylene fibres & 0.351 & 0.47 & 0.165 \\
\hline $10 \% \mathrm{Pd} / \mathrm{C}$ & Szilor $11 c^{21}$ & $10 \%$ Palladium on carbon & 0.275 & 0.94 & 0.258 \\
\hline
\end{tabular}

\section{Results and Discussion}

\section{Identification of the key parameters for catalyst testing}

For setting the parameters for catalyst evaluation we have chosen the following model reaction (Scheme 1) applying 1.2 eq. alkyne (1), 1 eq. aromatic halide, 3 eq. sodium hydroxide as a base 
and methanol as a solvent ( $\mathrm{c}=0.05 \mathrm{M}$ to the aromatic halide). The optimal concentration was found as $0.05 \mathrm{M}$, more concentrated solution led to incomplete reaction (decreased conversion). As an initial catalyst we have chosen polymer-bound $\mathrm{PdCl}_{2}\left(\mathrm{PPh}_{3}\right)_{2}$ (Entry 1, Table 1).

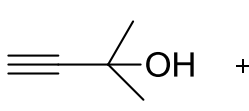

1<smiles>COc1ccc(I)cc1</smiles>

2

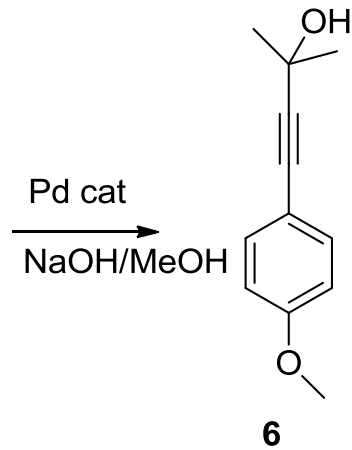

6

Scheme 1. Model reaction for the identification of the parameter set for catalyst testing.

Table 2. Parameters investigated for finding the optimal parameter set (flow rate, $\mathrm{T}$, $\mathrm{p}$ ) for the model reaction

\begin{tabular}{cccccc}
\hline Entry & $\begin{array}{c}\text { Flow rate } \\
(\mathrm{mL} / \mathrm{min})\end{array}$ & $\begin{array}{c}\text { Pressure } \\
(\mathrm{bar})\end{array}$ & $\begin{array}{c}\text { Temperature } \\
\left({ }^{\circ} \mathrm{C}\right)\end{array}$ & Conversion & $\begin{array}{c}\text { Size of the } \\
\text { CatCart } \\
(\mathrm{mm})\end{array}$ \\
\hline A & 0.5 & 50 & 100 & 48 & 30 \\
$\mathrm{~B}$ & 0.2 & 50 & 100 & 80 & 30 \\
$\mathrm{C}$ & 0.2 & 50 & 100 & 98 & 30 \\
$\mathrm{D}$ & 0.1 & 50 & 100 & 100 & 30 \\
$\mathrm{E}$ & 0.2 & 70 & 100 & 98 & 30 \\
$\mathrm{~F}$ & 0.2 & 70 & 100 & 92 & 70 \\
$\mathrm{G}$ & 0.1 & 50 & 100 & 92 & 70 \\
$\mathrm{H}$ & 0.1 & 100 & 100 & 95 & 70 \\
\hline
\end{tabular}

In order to save the large cartridges the parameter „scanning” was started with standard $30 \mathrm{~mm}$ cartridges. As a result $0.1 \mathrm{~mL} / \mathrm{min}$ flow rate, 100 bar and $100{ }^{\circ} \mathrm{C}$ was selected. During the reactions no acetylene dimerization was observed, which was expected in copper-free conditions. 
Table 3. The reaction matrix applied in the catalyst screening study

Entries Reactants

Entry $1(\mathrm{X}=\mathrm{I})$, Entry $4(\mathrm{X}=\mathrm{Br})$

Entry $2(\mathrm{X}=\mathrm{I})$, Entry $5(\mathrm{X}=\mathrm{Br})$
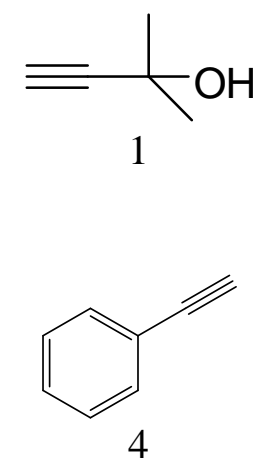

Entry $3(X=I)$, Entry $6(\mathrm{X}=\mathrm{Br})$

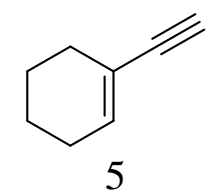

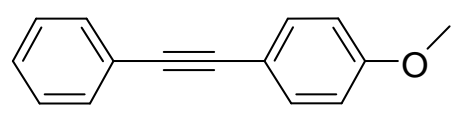

7

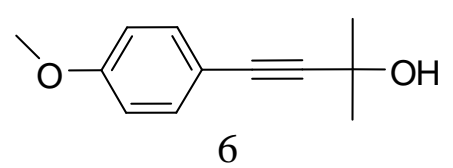

6

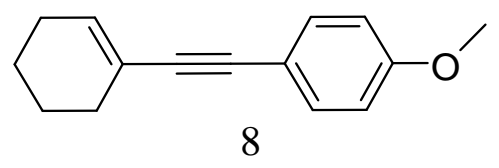

Table 4. The performance of the 4 catalysts in the 6 coupling reactions between terminal alkynes and aryl halides leading to aryl-(vinyl) acetylenes (6-8)

\begin{tabular}{|c|c|c|c|c|c|c|}
\hline Entry & $\begin{array}{l}\text { Flow rate } \\
(\mathrm{ml} / \mathrm{min})\end{array}$ & $\begin{array}{c}\text { Temperature } \\
\left({ }^{\circ} \mathrm{C}\right)\end{array}$ & $\begin{array}{c}\text { Pressure } \\
\text { (bar) }\end{array}$ & Catalyst & $\begin{array}{c}\text { Conversion } \\
(\%)\end{array}$ & $\begin{array}{c}\text { Selectivity } \\
(\%)\end{array}$ \\
\hline \multirow[t]{4}{*}{$\begin{array}{c}\text { Entry } 1 \\
(\mathbf{6})\end{array}$} & 0.1 & 100 & 100 & $\begin{array}{c}\mathrm{PdCl}_{2}\left(\mathrm{PPh}_{3}\right)_{2} \\
\mathrm{DVB}\end{array}$ & $95 \%$ & $51 \%$ \\
\hline & 0.1 & 100 & 100 & Fibrecat 1001 & $84 \%$ & $60 \%$ \\
\hline & 0.1 & 100 & 100 & Fibrecat 1007 & $92 \%$ & $66 \%$ \\
\hline & 0.1 & 100 & 100 & $10 \% \mathrm{Pd} / \mathrm{C}$ & $51 \%$ & $54 \%$ \\
\hline \multirow[t]{4}{*}{$\begin{array}{c}\text { Entry } 2 \\
\text { (7) }\end{array}$} & 0.1 & 100 & 100 & $\begin{array}{c}\mathrm{PdCl}_{2}\left(\mathrm{PPh}_{3}\right)_{2} \\
\mathrm{DVB}\end{array}$ & $>99 \%$ & $85 \%$ \\
\hline & 0.1 & 100 & 100 & Fibrecat 1001 & $93 \%$ & $95 \%$ \\
\hline & 0.1 & 100 & 100 & Fibrecat 1007 & $99 \%$ & $99 \%$ \\
\hline & 0.1 & 100 & 100 & $10 \% \mathrm{Pd} / \mathrm{C}$ & $19 \%$ & $69 \%$ \\
\hline
\end{tabular}


Table 4. Continue

\begin{tabular}{|c|c|c|c|c|c|c|}
\hline Entry & $\begin{array}{c}\text { Flow rate } \\
(\mathrm{ml} / \mathrm{min})\end{array}$ & $\begin{array}{c}\text { Temperature } \\
\text { (oC) }\end{array}$ & $\begin{array}{c}\text { Pressure } \\
\text { (bar) }\end{array}$ & Catalyst & $\begin{array}{c}\text { Conversion } \\
(\%)\end{array}$ & $\begin{array}{c}\text { Selectivity } \\
(\%)\end{array}$ \\
\hline \multirow[t]{4}{*}{$\begin{array}{c}\text { Entry } 3 \\
(\mathbf{8})\end{array}$} & 0.1 & 100 & 100 & $\begin{array}{c}\mathrm{PdCl}_{2}\left(\mathrm{PPh}_{3}\right)_{2} \\
\mathrm{DVB}\end{array}$ & $>99 \%$ & $85 \%$ \\
\hline & 0.1 & 100 & 100 & Fibrecat 1001 & $97 \%$ & $97 \%$ \\
\hline & 0.1 & 100 & 100 & Fibrecat 1007 & $95 \%$ & $85 \%$ \\
\hline & 0.1 & 100 & 100 & $10 \% \mathrm{Pd} / \mathrm{C}$ & $53 \%$ & $75 \%$ \\
\hline \multirow[t]{4}{*}{$\begin{array}{c}\text { Entry } 4 \\
(\mathbf{6})\end{array}$} & 0.1 & 100 & 100 & $\begin{array}{c}\mathrm{PdCl}_{2}\left(\mathrm{PPh}_{3}\right)_{2} \\
\mathrm{DVB}\end{array}$ & $89 \%$ & $99 \%$ \\
\hline & 0.1 & 100 & 100 & Fibrecat 1001 & $50 \%$ & $41 \%$ \\
\hline & 0.1 & 100 & 100 & Fibrecat 1007 & $8 \%$ & $60 \%$ \\
\hline & 0.1 & 100 & 100 & $10 \% \mathrm{Pd} / \mathrm{C}$ & $1 \%$ & $99 \%$ \\
\hline \multirow[t]{4}{*}{$\begin{array}{c}\text { Entry } 5 \\
(\underline{7})\end{array}$} & 0.1 & 100 & 100 & $\begin{array}{c}\mathrm{PdCl}_{2}\left(\mathrm{PPh}_{3}\right)_{2} \\
\mathrm{DVB}\end{array}$ & $42 \%$ & $52 \%$ \\
\hline & 0.1 & 100 & 100 & Fibrecat 1001 & $36 \%$ & $56 \%$ \\
\hline & 0.1 & 100 & 100 & Fibrecat 1007 & $14 \%$ & $25 \%$ \\
\hline & 0.1 & 100 & 100 & $10 \% \mathrm{Pd} / \mathrm{C}$ & $2 \%$ & $2 \%$ \\
\hline \multirow[t]{4}{*}{$\begin{array}{c}\text { Entry } 6 \\
(\mathbf{8})\end{array}$} & 0.1 & 100 & 100 & $\begin{array}{c}\mathrm{PdCl}_{2}\left(\mathrm{PPh}_{3}\right)_{2} \\
\mathrm{DVB}\end{array}$ & $50 \%$ & $47 \%$ \\
\hline & 0.1 & 100 & 100 & Fibrecat 1001 & $44 \%$ & $84 \%$ \\
\hline & 0.1 & 100 & 100 & Fibrecat 1007 & $31 \%$ & $60 \%$ \\
\hline & 0.1 & 100 & 100 & $10 \% \mathrm{Pd} / \mathrm{C}$ & $0 \%$ & - \\
\hline
\end{tabular}

Note: The definition of selectivity is widely used in the catalytic science as the following: $S_{\mathrm{i}}=$ $\mathrm{n}_{\mathrm{i}} / \sum \mathrm{n}_{\mathrm{k}} * 100$, where $i$ is the target product in a mixture of $k$ products, excluding the reagent residues.

\section{Investigation of catalyst longevity}

Catalyst longevity is one of the key concerns in any catalytic processes. We investigated one of the best performing catalysts $\left(\mathrm{PdCl}_{2}\left(\mathrm{PPh}_{3}\right)_{2}, \mathrm{DVB}\right)$ in 4 reactions (Entry 2,3,4,5) for repeated performance. We collected $4 \mathrm{~mL}$ samples (Fractions 1-5) in continuous operation and the samples were analyzed by LC-MS for conversion. As it is shown in Table 5. the longevity is strongly dependent on the structures. Interestingly for Entry 2 the conversion dropped very rapidly. Since as it was previously shown the selectivity was rather poor for $\mathrm{PdCl}_{2}\left(\mathrm{PPh}_{3}\right)_{2}, \mathrm{DVB}$ in Entry 2, which might be due to significant leaching of the catalyst and the polymers in the presence of phenyl-acetylene that led to unidentified impurities (see also under Conclusion). Similarly in Entry 5 where the coupling agent was again phenyl-acetylene the conversion also dropped but the starting value was also rather poor. In the other two cases the stability and the performance was acceptable for this polymer-bound catalyst. 
Table 5. Conversion rates of the coupling reaction of various reactants under continuous operation in the subsequently collected fractions

\begin{tabular}{lcccc}
\hline & Entry 2 & Entry 3 & Entry 4 & Entry 5 \\
\hline Fraction 1 & $>99 \%$ & $>99 \%$ & $\sim 89 \%$ & $42 \%$ \\
Fraction 2 & $87.5 \%$ & $>99 \%$ & $\sim 89 \%$ & $42 \%$ \\
Fraction 3 & $71 \%$ & $>99 \%$ & $\sim 91 \%$ & $32 \%$ \\
Fraction 4 & $53 \%$ & $>99 \%$ & - & $22 \%$ \\
Fraction 5 & $32 \%$ & $>99 \%$ & - & $21 \%$ \\
\hline
\end{tabular}

\section{Conclusions}

The present study aimed at demonstrating the potential of flow technology in real-time catalyst screening. Table 6 shows the best performing catalysts for each reaction (Entry 1-6).

Table 6. Summary table of the best performing catalysts based on the results obtained in the test reactions

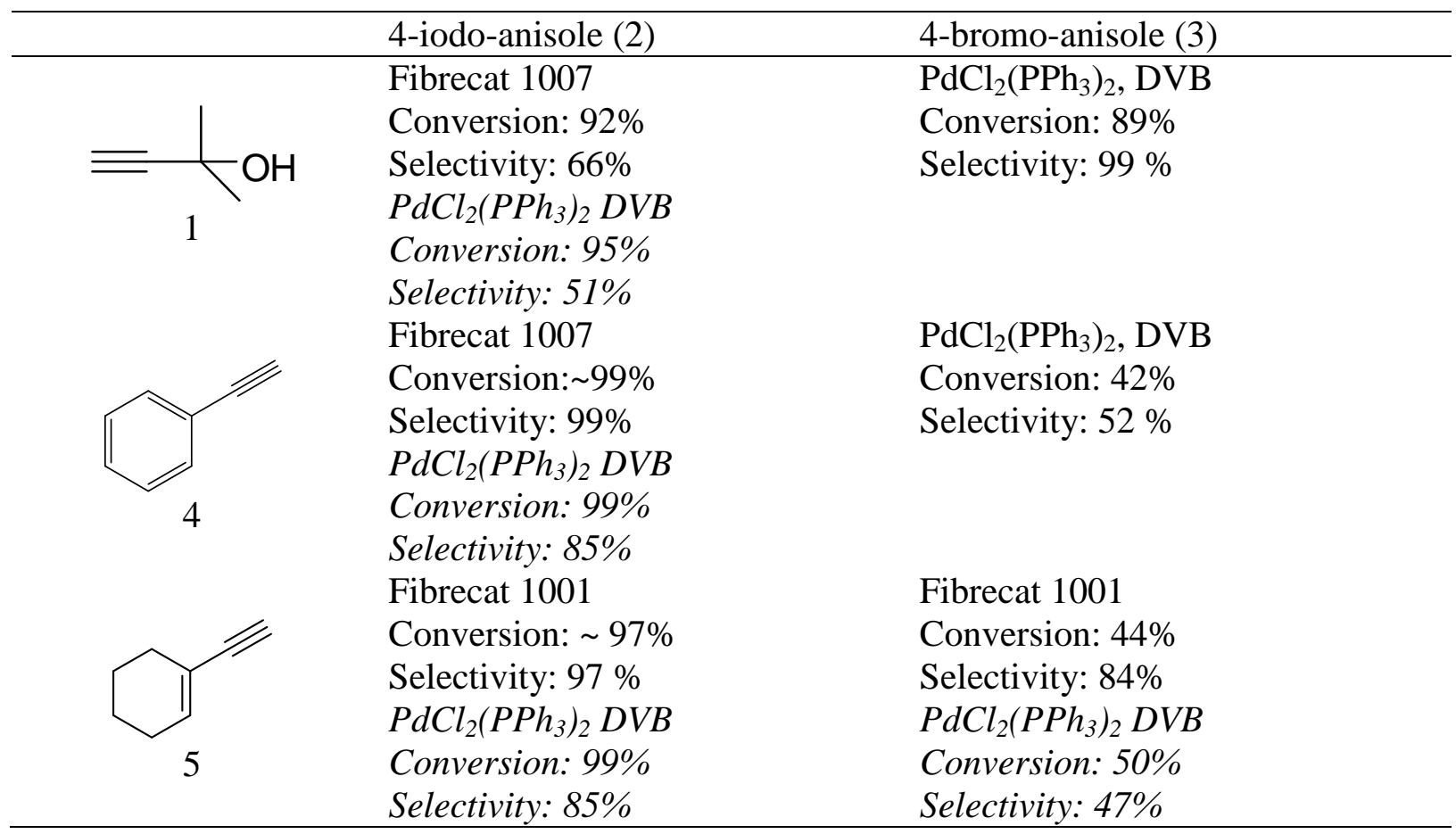

For coupling the alkynes with 4-iodo-anisole the Fibrecat types of catalysts showed the highest performance if both the conversion and the selectivity were taken into consideration. For 4-iodo-anisole $\mathrm{PdCl}_{2}\left(\mathrm{PPh}_{3}\right)_{2}$, DVB showed higher conversion but LC-MS showed significant 
amount of unknown impurities, thus, the selectivity was lower particularly for Entry 1 (51\%). On the other hand when 4-bromo-anisole was applied as the aromatic halide coupling reagent $\mathrm{PdCl}_{2}\left(\mathrm{PPh}_{3}\right)_{2}$, DVB gave superior results including both conversion and selectivity. For phenylacetylene and ethynyl-cyclohexene the coupling of the bromo species resulted in low conversion as well as selectivity for most of the polymer-bound catalysts but Fibrecat 1001 showed relatively good selectivity for ethynyl-cyclohexene. This study confirms that catalyst evaluation using flow devices allows a rapid evaluation and selection of the most appropriate catalysts and since the performance is strongly dependent on nature of reactants. For the cheap and simple catalyst, $10 \% \mathrm{Pd} / \mathrm{C}$ coupling reaction was only achieved with the more reactive 4-iodo-anisole (highest conversion: 53\%, Entry 3), while with 4-bromo-anisole essentially no coupling reaction was observed.

In conclusion, if considering that each catalyst evaluating reaction lasts approx. 10 min plus another approx. $10 \mathrm{~min}$ for washing the system, for completing such reaction matrix of 24 reactions ( 6 reactions x 4 catalyts) it requires 8 hours. Performing the HPLC evaluation can be done in parallel. Thus, the striking advantage of continuous flow devices is the rapid parameter optimization as well as rapid screening to find the best catalyst for a particular reaction. Performing catalyst screening in flow can be automated using pre-programmed catalyst cartridge changing (e.g. CatCart Changer ${ }^{22}$ ) and a fraction collector, thus, the evaluation experiments can be carried out overnight and unattended.

\section{Experimental Section}

General. Sonogashira coupling was performed using H-Cube fixed-bed flow reactor in "no gas" mode. $^{23}$ The conversion and selectivity was determined by HPLC-MS comparing the area percentage with calibration results obtained at various concentrations. For LC-MS experiments Agilent 1100 liquid chromatograph was linked with Waters Micromass ZQ mass spectrometer using atmospheric-pressure chemical ionization (APCI) technique. ${ }^{1} \mathrm{H}$ NMR spectra were recorded on Bruker Avance II $400 \mathrm{MHz}$.

Sonogashira coupling reaction in continuous flow. A methanolic solution was prepared containing $0.05 \mathrm{M}$ (1 eq.) aromatic halide, 1.2 eq. alkyne and 3 eq. sodium hydroxide. The HCube system was flushed with methanol for $10 \mathrm{~min}$ in order to wet the catalysts. After such conditioning the parameters $\left(100^{\circ} \mathrm{C}, 100 \mathrm{bar}\right)$ were set and the previously prepared solution was pumped through the $\mathrm{H}$-Cube system in ,no gase" mode at $0.1 \mathrm{~mL} / \mathrm{min}$ flow rate. The solution containing the product was then collected. Isolation of the product: The methanolic solution was diluted with dichloromethane and washed with water, then brine and finally dried over $\mathrm{MgSO}_{4}$. Whenever it was necessary the product was purified with column chromatography (Eluent: hexane $=$ EtOAc 20:1). For each reaction the products were isolated and their structure was identified by ${ }^{1} \mathrm{H}$ NMR comparing the spectra with previously reported results. In the cases 
where the selectivity was low the separation of the required product from the impurities was rather challenging by flash chromatography and the recovery of the compounds was sometimes also poor, thus, the isolated yield of the pure products was often about 50-55 \%

HPLC-MS analysis. Mobile phase A is composed of $1860 \mathrm{~mL}$ water/100 mL acetonitrile/40 mL ammonium formiate buffer. Mobile phase B is composed of $1600 \mathrm{~mL}$ acetonitrile/360 mL water/ $40 \mathrm{~mL}$ buffer. The buffer was prepared by mixing $220 \mathrm{~mL} 25 \%$ aqueous $\mathrm{NH}_{4} \mathrm{OH}, 100 \mathrm{~mL}$ formic acid and $2000 \mathrm{~mL}$ water. Stationary phase: Lichrocart C18 (Merck). Flow rate: $1.5 \mathrm{~mL} / \mathrm{min}$ Gradient elution applied: Starting with 100\% A/0 \% B; then within 4 min B was increased to $100 \%$; maintained for another $2 \mathrm{~min}$ at $100 \% \mathrm{~B}$; followed by returning to $100 \% \mathrm{~A}$ within additional 4 min.

Injection: $5 \mu \mathrm{L}$ from the collected reaction solution

4-(4-Methoxyphenyl)-2-methylbut-3-yn-2-ol (6). ${ }^{1} \mathrm{H} \mathrm{NMR}\left(400 \mathrm{MHz}, \mathrm{CDCl}_{3}\right)$ : $\delta$ 7.37-7.33 (m, $2 \mathrm{H}), 6.84-6.81(\mathrm{~m}, 2 \mathrm{H}), 3.80(\mathrm{~s}, 3 \mathrm{H}), 2.04(\mathrm{bs}, 1 \mathrm{H}), 1.61(\mathrm{~s}, 6 \mathrm{H}) ; \mathrm{m} / \mathrm{z} 191 \mathrm{M}+1$; Retention time (LC-MS): $3.42 \mathrm{~min}$.

The NMR and MS spectra correspond to the literature data. ${ }^{24,25}$

1-Methoxy-4-(2-phenylethynyl)benzene (7). ${ }^{1} \mathrm{H} \mathrm{NMR}\left(400 \mathrm{MHz}, \mathrm{CDCl}_{3}\right): \delta$ 7.52-7.49 (m, 2H), 7.48-7.45 (m, 2H), 7.33-7.31 (m, 3H), 6.89-6.85 (m, 2H), 3.81 (s, 3H); Retention time (LC-MS): $5.67 \mathrm{~min}$; $\mathrm{m} / \mathrm{z}, 209 \mathrm{M}+1$.

The NMR and MS spectra correspond to the literature data. ${ }^{8,25,26,27}$

1-[2-(Cyclohex-1-en-1-yl)ethynyl]-4-methoxybenzene (8). ${ }^{1} \mathrm{H}$ NMR (400 MHz, $\left.\mathrm{CDCl}_{3}\right): \delta 7.35$ $(\mathrm{J}=8.7,2 \mathrm{H}), 6.82(\mathrm{~J}=8.7,2 \mathrm{H}), 6.17(\mathrm{~m}, 1 \mathrm{H}), 3.80$ (s, 3H), 2.26-2.10 (bm, 4H), 1.72-1.57 (bm, 4H); Retention time (LC-MS): $5.32 \mathrm{~min}$; $\mathrm{m} / \mathrm{z} 213 \mathrm{M}+1$.

The NMR and MS spectra correspond to the literature data. 8,25

\section{Acknowledgements}

This work was partially supported by the National Development Agency KMOP 1.1.4 grant (\#KMOP-1.1.4-09-2010-0145).

\section{References}

1. Sonogashira, K.; Tohda, Y.; Hagihara, N. Tetrahedron Lett. 1975, $50,4467$.

2. Chinchilla, R.; Nájera, C. Chem. Rev. 2007, 107, 874.

3. Awuah, E.; Capretta, A. Org. Lett. 2009, 11, 3210.

4. Appukkuttan, P.; Dehaen, W.; Eycken, E. V. d. Eur. J. Org. Chem. 2003, 24, 4713.

5. Leadbeater, N. E.; Marco, M.; Tominack, B. J. Org. Lett. 2003, 5, 3919.

6. Chen, G.; Zhu, X.; Cai, J; Wan, Y. Synthetic Comm. 2007, 37, 1355. 
7. Darvas, F.; Dormán, G.; Lengyel, L.; Kovács, I.; Jones, R.; Ürge, L. Chim. Oggi 2009, 27, 40-43.

8. Fukuyama, T.; Shinmen, M.; Nishitani, S.; Sato, M.; Ryu, I. Org. Lett. 2002, 4, 1691.

9. Kawanami, H.; Matsushima, K.; Sato, M.; Ikushima, Y.; Angew. Chem. Int. Ed. 2007, 46, 5129.

10. Sugimoto, A.; Fukuyama, T.; Rahman, M. T.; Ryu, I. Tetrahedron Lett. 2009, 50, 6364 .

11. Javaid, R., Kawanami, H.; Chatterjee, M.; Ishizaka, T.; Suzuki, A.; Suzuki, T. M. Chem. Eng. J. 2011, 167, 431.

12. Kirschning, A.; Solodenko, W.; Mennecke K. Chem.-Eur. J. 2006, 12, 5972.

13. Frost, C. G.; Mutton, L. Green Chem. 2010, 12, 1687.

14. Kovacs, I.; Jones, R.; Ötvös, Z.; Ürge, L.; Dormán, G.; Darvas, F. In Heterogeneous Catalysis Research Progress; Gunther M. B. Ed., Nova Science Publishers, New York, 2008, p 395.

15. Akiyama, R.; Kobayashi, S. Chem. Rev. 2009, 109, 594.

16. Goemann, A.; Deverell, J. A.; Munting, K. F.; Jones, R. C.; Rodemann, T.; Canty, A. J.; Smith, J. A.; Guijt, R. M. Tetrahedron 2009, 65, 1450.

17. Jones, R.; Godorhazy, L.; Varga, N.; Szalay, D.; Urge, L.; and Darvas, F. J. Comb. Chem.; 2006, $8,110$.

18. http://www.thalesnano.com/products/catcart

19. http://www.sigmaaldrich.com

20. http://www.jmcatalysts.com/

21. http://www.szilor.hu/

22. http://www.thalesnano.com/products/catcartchanger

23. http://www.thalesnano.com/products/h-cube

24. Lin, B.-N.; Huang S.-H.; Wu W.-Y.; Mou C.-Y.; Tsai F.-Y. Molecules 2010, 15, 9157.

25. Ma, Y.; Song, C.; Jiang, W.; Wu, Q.; Wang, Y.; Liu, X.; Andrus, M. B. Org. Lett. 2003, 5, 3317.

26. Hill, L. L.; Smith, J. M.; Brown, W. S.; Moore, L. R.; Guevera, P.; Pair, E. S.; Porter, J.; Chou, J.; Wolterman C. J.; Craciun, R.; Dixon, D. A.; Shaughness, K. H. Tetrahedron 2008, 64, 6920.

27. Hierso J.-C.; Fihri, A.; Amardeil, R.; Meunier, P.; Doucet, H.; Santelli, M. Tetrahedron 2005, 61, 9759 . 